\title{
Ações intersetoriais para promoção de saúde no sistema prisional
}

\section{Intersectoral actions for health promotion in the prison system}

DOI: $10.46814 /$ lajdv4n1-014

Recebimento dos originais: 01/01/2021

Aceitação para publicação: 28/02/2022

\section{Ana paula da silva uberti \\ Bacharel em psicologia PUCRS; Licenciada em psicologia UFRGS}

Especialista em arteterapia - faculdade vicentina do paraná especialista em gestão em saúde prisional - fiocruz- MS

Especialista em psicologia jurídica e forense - UNYLEYA

Especialista em avaliação psicológica e psicodiagnostico - UNYLEYA

superintendência dos serviços penitenciários, secretaria de justiça e sistemas penal e socioeducativo

penitenciária modulada estadual do osório

E-mail: a.p.uberti@gmail.com

\section{RESUMO}

Este projeto de intervenção objetivou a realização de ações intersetoriais para a promoção de saúde, especialmente a saúde mental. As atividades ocorreram durante o ano de 2013 e 2014 e foram fruto do estabelecimento de redes de parceria entre diversos setores da sociedade. Participaram da análise situacional 45 mulheres as quais encontravam-se no Anexo Feminino da Penitenciária Modulada Estadual de Montenegro. As atividades oferecidas às apenadas envolveram a arte, música, religião, saúde e trabalho, tendo como objetivo o desenvolvimento de ações que promovessem a saúde em amplo aspecto. Independente do objetivo da atividade proposta, abrir as portas das instituições prisionais para a sociedade é uma forma de compartilhar a responsabilidade sobre o motivo que traz tantas pessoas ao cárcere.

Palavras chaves: promoção de saúde, sistema prisional, mulheres.

\begin{abstract}
This study aimed to the realization of intersectoral action to promote health, especially mental health. Activities occurred during the year 2013 and 2014 and were the result of networking partnership among various sectors of society. Participated in the situational analysis which 45 women were in the Female Penitentiary Annex Modulated State of Montenegro. The activities offered at involving art, music, religion, health and work, aiming to develop actions that promote health in its broadest aspect. Regardless of the purpose of the proposed activity, open the doors of the prisons to society is a way to share responsibility for the reason that brings so many people to prison.
\end{abstract}

Keywords: health promotion, prison system, women. 


\section{ASPECTOS INTRODUTÓRIOS}

Quando pensamos em tratamento penal dentro das prisões logo nos vem à mente projetos voltados para dependência química, ações que reduzam os índices de tuberculose e doenças infectocontagiosas, atividades que visam a formação de sujeitos aprisionados, e tudo mais que possa resgatar possibilidades de reintegração sociais aos privados de liberdade.

Por todo o Brasil é possível verificar o empenho de profissionais em diferentes áreas objetivando minimizar os efeitos da pobreza e da falta de oportunidades da clientela com quem lidamos, produzindo projetos e ações que resignifiquem a vida das pessoas para que não regressem ao sistema penitenciário novamente: conforme o que vislumbra a Lei de Execução Penal.

$\mathrm{Na}$ contramão disso temos a precarização dos recursos humanos e materiais para o desenvolvimento do tratamento penal, os grandes índices de avaliações para progressão de regime as quais absorvem grande parte do tempo dos profissionais responsáveis, além daquilo que tange as mudanças de gestão dentro das instituições e as questões políticas.

A partir disso cabe pensarmos em ações que beneficiem o maior número possível de pessoas e que os temas propostos sejam atrativos a ponto de incentivar a participação dos apenados e estreitar as relações destes com os profissionais que trabalham para a sua "recuperação".

\section{DEFINIÇÃO DO PROBLEMA}

A penitenciária Estadual Modulada de Montenegro está localizada na zona rural do município em um espaço de difícil acesso. É uma penitenciária predominantemente masculina com capacidade de engenharia para 476 presos e um anexo feminino com disponibilidade de 112 vagas. O número de pessoas que se encontram aprisionadas varia entre 600 a 700, as quais, no momento, podemos encontrar homens e mulheres dentre estes, $\mathbf{6 3 5}$ homens e $\mathbf{5 8}$ mulheres.

Segundo dados do Ministério da Justiça e Departamento Penitenciário Nacional através do Sistema Integrado de Informações Penitenciárias (INFOPEN) em dezembro de 2012, o Estado do Rio Grande do Sul possuía 1.902 mulheres presas, sendo que 868 mulheres encontravam-se reclusas em regime fechado, 420 em regime semiaberto, 50 contidas em regime aberto, 16 em medida de segurança e internação, 53 em medida de segurança e 495 em prisão provisória. Conforme dados levantados pelo Departamento de Planejamento, do ano de 1995 até a data atual, houve um incremento do efetivo carcerário feminino de 517,57\%. Observa-se que tal proporção em comparação com o crescimento da população masculina no sistema penitenciário de $151,35 \%$, apresentou um índice 3 vezes mais elevado. ${ }^{6}$

Diante desta realidade alarmante em relação ao público feminino, e conforme demanda do pósgraduação em Gestão em Saúde Prisional iniciamos o trabalho de análise situacional através da 
aplicação de uma pesquisa quanto ao perfil das mulheres aprisionadas no Anexo Feminino da Penitenciária Estadual Modulada de Montenegro. A equipe de saúde elencou os seguintes quesitos para aplicação da pesquisa: idade, naturalidade, estado civil, profissão, escolaridade, número de filhos, renda familiar, trabalho prisional, visita na penitenciária, e uso de drogas. Estas categorias foram elegidas, pois acreditamos que estas informações possam traduzir com maior clareza o perfil de pessoas com quem trabalhamos. Das 57 mulheres em situação de aprisionamento, 48 responderam ao questionário.

Os resultados apresentados nos chama atenção em diversos aspectos. Quanto ao que motivou o ingresso das mulheres no cárcere nos deparamos com a seguinte realidade:

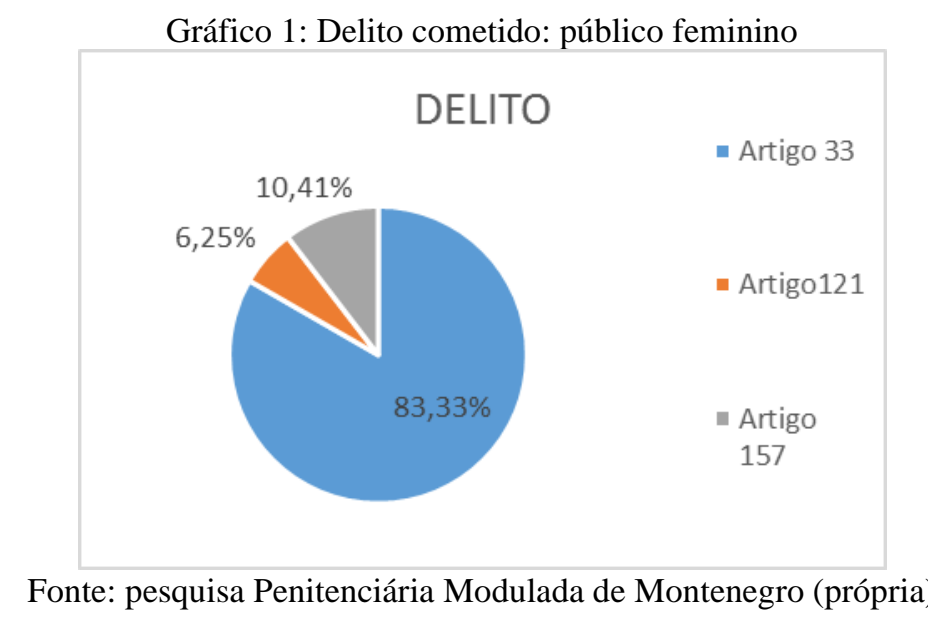

O resultado de $83,33 \%$ de ingresso em função do tráfico de drogas é algo que nos chama para a reflexão. O tráfico de drogas transformou-se em um negócio de família, assim como o uso de drogas transformou-se em uma pandemia. ${ }^{1}$

As sobrecargas de privações às mulheres caracterizam-se por sua especificidade em decorrência da "punição moral" que acompanha a pena. As mulheres além de terem rompido as normas jurídicas, rompem com o ideal materno de "boa" esposa, aspectos que se caracterizam como múltiplas penalizações às mulheres presas. Sendo assim, encontramos uma grande parte das mulheres aprisionadas sem receber visitas, ou sendo criticadas pela família a qual acaba não apoiando-as durante o tempo em que cumprem pena. Muitas mulheres ainda passam pelo dilema de não ter com que deixar seus filhos, ou sofrendo com a ausência dos mesmos durante o cumprimento de pena pela proibição legal da entrada de crianças em ambientes prisionais. ${ }^{9}$

Claro que encontramos situações de mulheres que realmente são usuárias de drogas e que acabam envolvendo-se no tráfico por conta deste problema de saúde. A partir disso, torna-se relevante apresentarmos os índices para o uso de drogas. 
Gráfico 2 - uso de drogas da população feminina

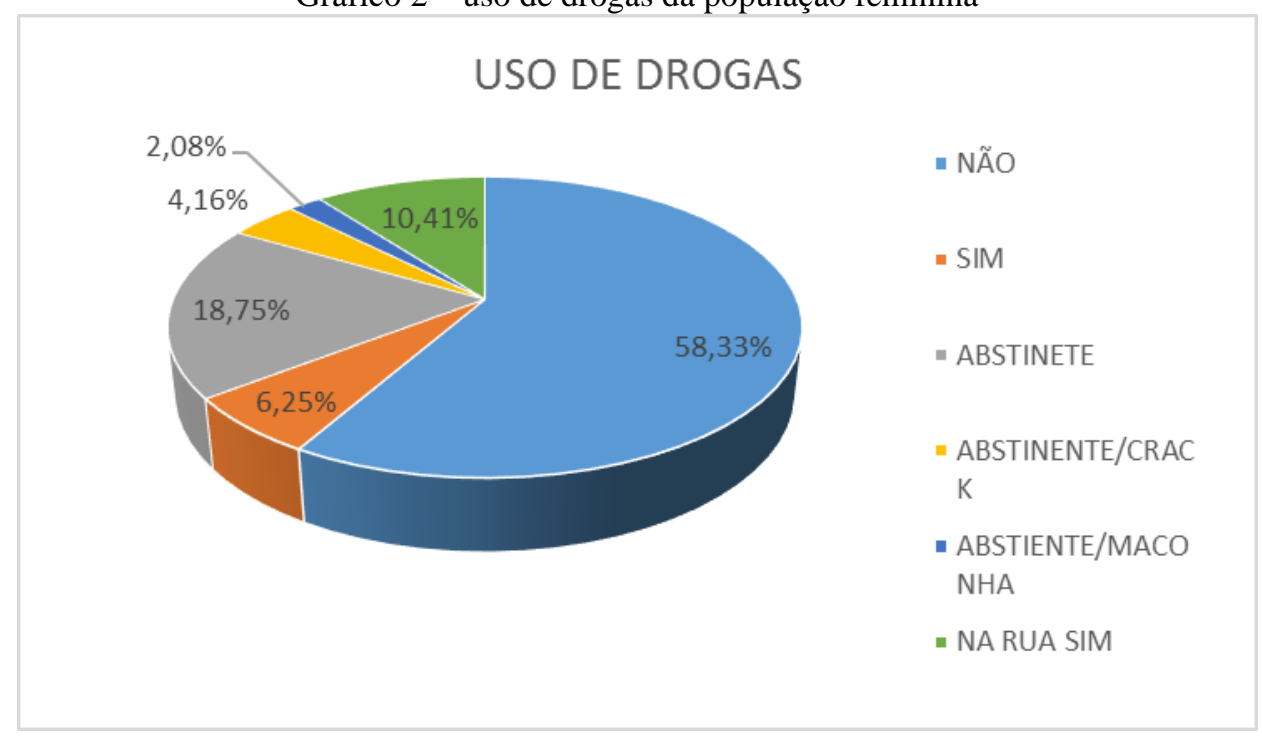

Fonte: pesquisa Penitenciária Modulada de Montenegro (própria)

Apesar da equipe ter um bom diálogo com as mulheres entrevistadas devemos considerar que as informações sofrem interferências metodológicas, pois muitas têm medo de falar à respeito do uso de substâncias, o que envolve outros aspectos dentro da prisão, tendo 58,33\% das entrevistadas declaradas como não usuárias de drogas. Em contrapartida, temos 83,33\% presas pelo tráfico de drogas, sendo que a maioria diz não ser traficante. Diante esta situação, nos cabe questionar: Temos um problema de saúde ou social?

Tão relevante como o delito é a idade com que as mulheres ingressam no sistema penitenciário

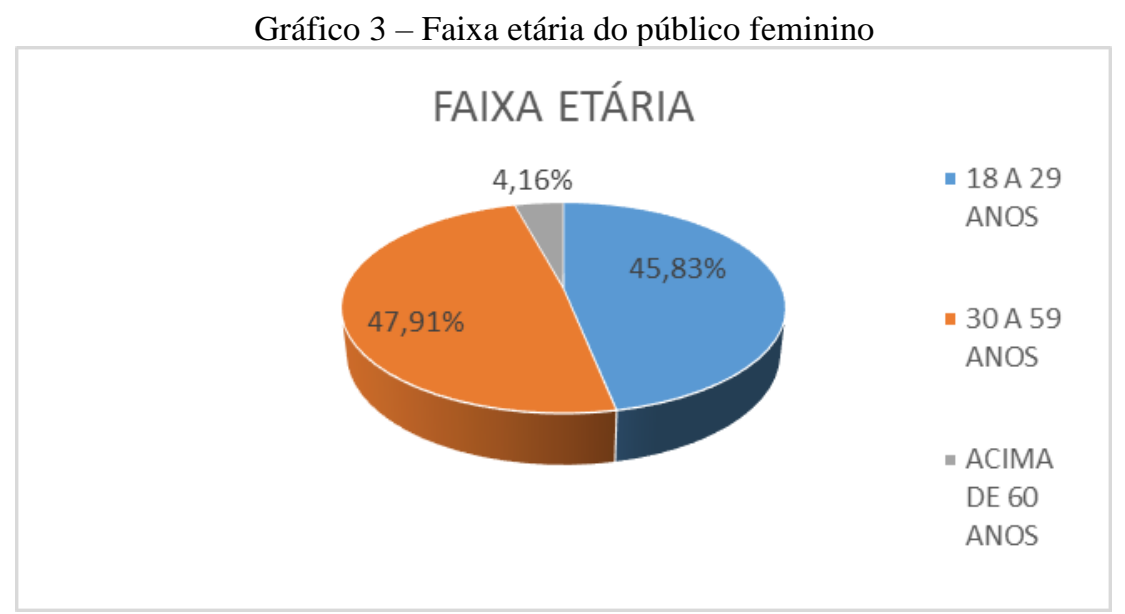

Fonte: pesquisa Penitenciária Modulada de Montenegro (própria)

Estes dados nos mostram a precocidade em que estas mulheres foram aprisionadas. Conforme dados do Plano Nacional de Saúde Prisional a população carcerária é, em sua grande maioria, do sexo masculino e insere-se na faixa etária de 18 a 29 anos, não tendo pesquisas realizadas com o público feminino. ${ }^{3}$ Conforme a pesquisa, $48 \%$ das mulheres entrevistadas são adultos-jovens, ou seja, tanto 
homens quanto mulheres que compõe o sistema penitenciário estão nesta faixa etária. Já em relação à escolaridade:

Gráfico 4: Escolaridade do público feminino

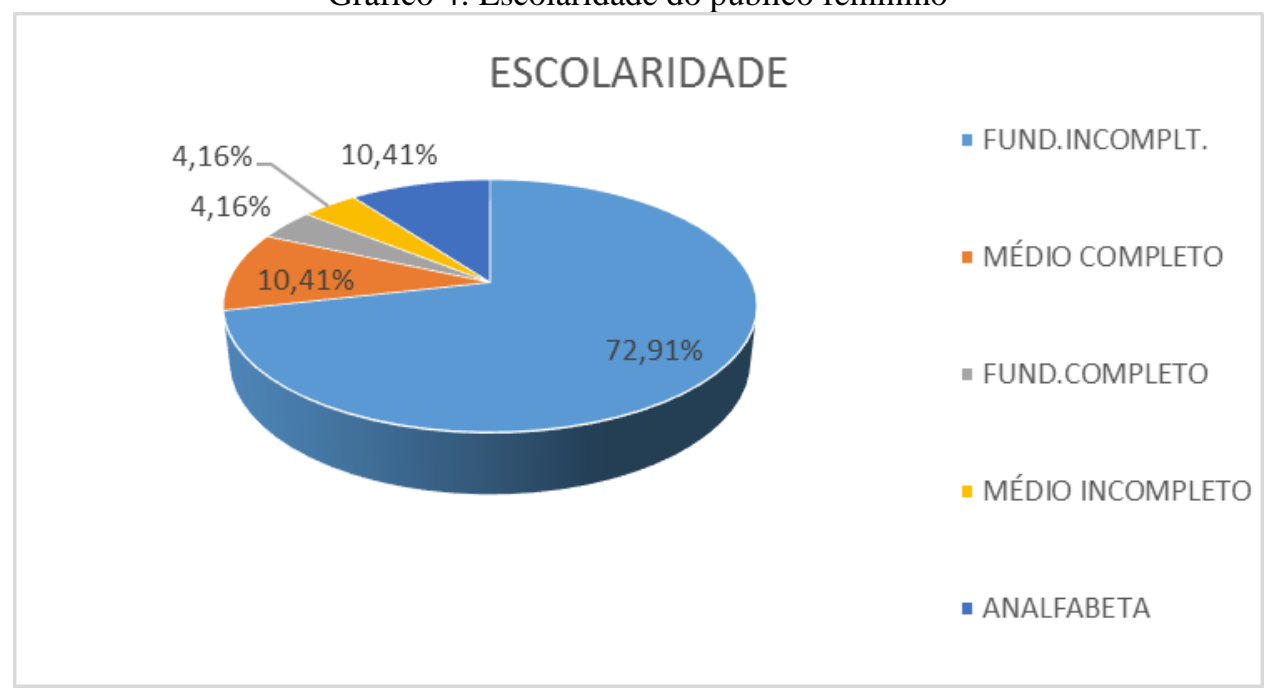

Fonte: pesquisa Penitenciária Modulada de Montenegro (própria)

Tão importante quanto a escolaridade dos indivíduos de uma população é a profissão que os mesmos desenvolvem. Ao falarmos em escolaridade e profissão falamos também em qualidade de vida e saúde dos indivíduos. Segue abaixo o panorama de atividades laborais antes de ingressar no cárcere.

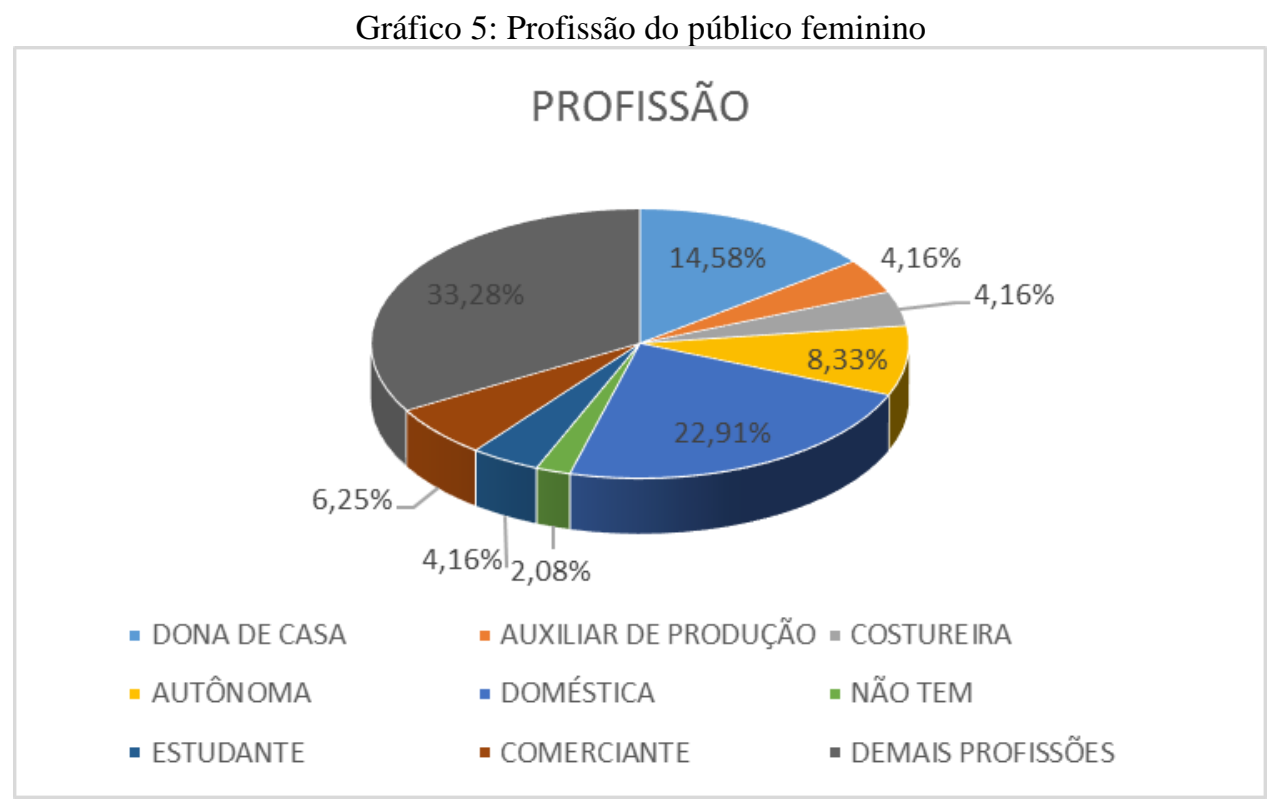

Fonte: pesquisa Penitenciária Modulada de Montenegro (própria)

As profissões declaradas na pesquisa revelam a informalidade laboral ou seja, a grande maioria das mulheres não possui vínculo empregatício e muitas são "mães de família", ou seja, sustentam a família sozinhas e lidam com a instabilidade de atividades são vínculo. Atualmente no Brasil esta é 
uma realidade muito frequente num grupo específico de pessoas, o que fica bem claro neste grupo de pessoas que encontram-se no cárcere.

Fazendo um paralelo entre as profissões exercidas antes e durante o cárcere encontramos informações interessantes. Segue abaixo o retrato do trabalho prisional para o público feminino:

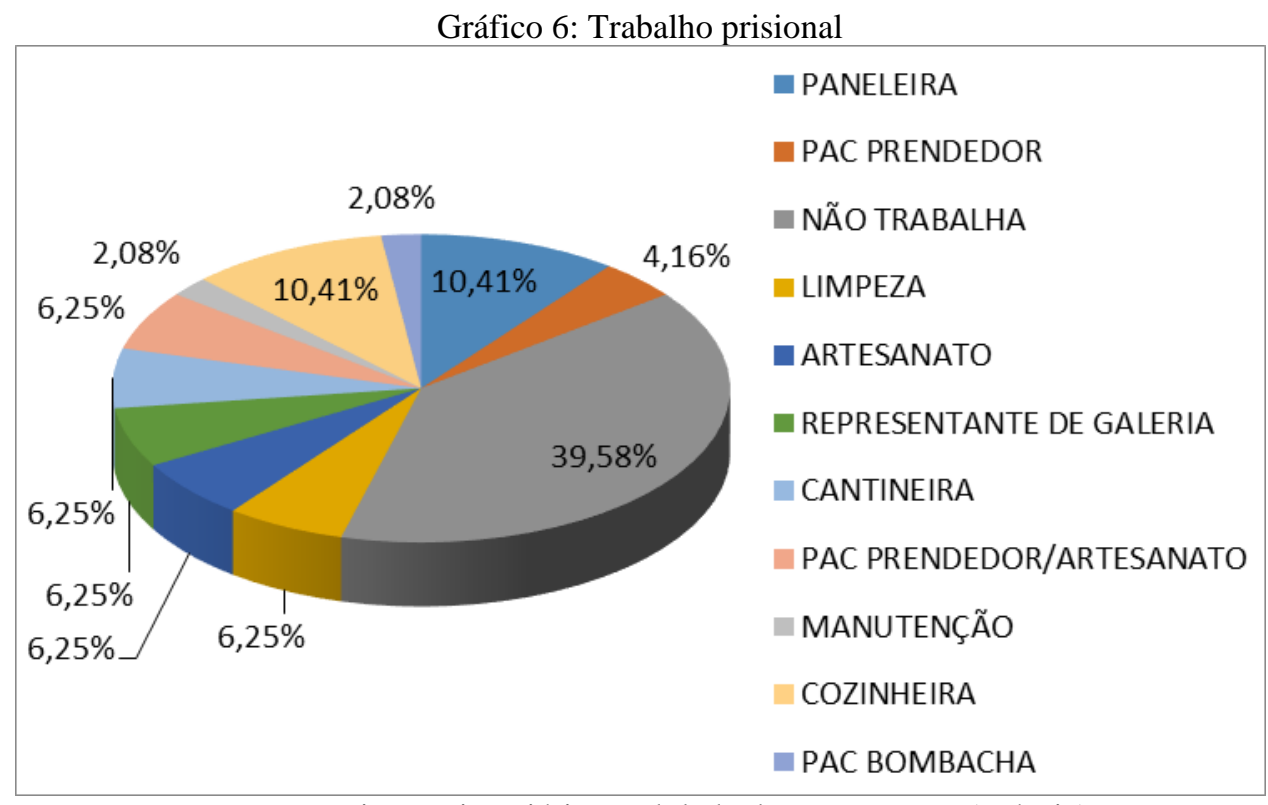

Fonte: pesquisa Penitenciária Modulada de Montenegro (própria).

De acordo com a Lei de Execuções Penais (art. 28, 1984): "O trabalho do condenado, como dever social e condição de dignidade humana, terá finalidade educativa e produtiva". Ainda podemos comentar que o trabalho gera remissão de pena, sendo descontado um dia da pena, a cada três dias trabalhados. ${ }^{3}$

Algumas detentas desenvolvem atividades que lhe oportunizam aprendizados técnico como o Protocolo de Ação Conjunta que é uma parceria entre a penitenciária e empresas que tenham interesse em montar uma linha de produção dentro de casas prisionais. No caso da Penitenciária Modulada de Montenegro temos o (PAC) das bombachas, onde 6,25\% das mulheres participam e que pode render de $\mathrm{R} \$ 150,00$ a $\mathrm{R} \$ 450,00$. Os PAC prendedores $(6,25 \%)$ paga $\mathrm{R} \$ 15,00$ por saco de prendedores produzidos.

Destaca-se que a maioria das atividades ofertadas e realizadas pelas mulheres, caracterizam-se pela manutenção doméstica do espaço prisional, tal como a limpeza, a cozinha e o serviço de entrega de alimentos, atividades que reproduzem o contexto da profissional informal. "A diferença no acesso ao trabalho, é explicada pela imagem que o coletivo constrói da mulher presa” (ESPINOZA $\left.{ }^{8}, 2004\right)$. Sendo assim, acreditamos ser natural que as mulheres atuem nestas frentes de trabalho. Neste sentido cabe citarmos: 
"Cenas cotidianas que se instituem no interior dos estabelecimentos, que se não forem problematizadas, podem contribuir ao discurso punitivo que se produz a partir das relações de gênero naturalizando desigualdades". (JARDIM", 2007)

Diante desta realidade cabe referirmos os dados referente ao público masculino, onde apenas 25,76\% dos homens não trabalham, sendo oferecido, além dos PAC's Bombachas e Prendedores, o PAC Ello (condutores elétricos), costura de bolas, e chaveiros, sem pronunciar as outras ligas laborativas como planilheiro, auxiliar jurídico, barbeiro e auxiliar de consultório de enfermagem, os quais não são ofertados ao público feminino.

A partir de todos os dados levantados a equipe de saúde conseguiu identificar o perfil da população feminina com que trabalhamos. Somado a isso temos outros aspectos de ordem da instituição que caracterizam a população em pauta e que demarcam o território de vulnerabilidades que possuímos no campo de pesquisa. Sendo assim, seguimos para a definição de ações.

\section{DEFINIÇÃO DA AÇÃO}

O objetivo da definição do problema é poder identifica-lo para que seja possível estabelecer ações que venham a minimizar os efeitos do problema. ${ }^{10}$

O aprisionamento feminino gera muitas repercussões dentro do ambiente carcerário. As solicitações de atendimentos são muito mais frequentes para o público feminino do que masculino, além disso, possuem naturezas diversas, mas especialmente no que se refere ao sofrimento psíquico diante o encarceramento. Ao debater com a equipe a realidade o panorama de situações de vulnerabilidade apresentadas pelo público em pauta entendemos que priorizar um tema incorreria na falha de negar a diversidade de questões que se apresentaram na clientela feminina com quem trabalhamos. A partir disso, optamos por buscar oportunidades que contribuam num amplo espectro da vida destas pessoas tendo como principal estratégia uma ação intersetorial a qual abrangeria diferentes aspectos de vida do nosso público.

A saúde pública veio num crescente de avanços quanto a forma de tratar seus usuários. Da reforma sanitária à luta antimanicomial a ideia de saúde mental segue a política do cuidado com a estratégia de projetos terapêuticos que procuram singularizar o sujeito ou mesmo o coletivo tendo um conjunto de ações terapêuticas articuladas por equipe multidisciplinar com participação ativa dos sujeitos envolvidos. ${ }^{4}$

De acordo com Buss ${ }^{6}$ o conceito atual de Promoção da Saúde está ligado a um conjunto de valores de vida (saúde, solidariedade, equidade, democracia, cidadania, bem estar, desenvolvimento sustentável, participação e parceria) relacionado a uma junção de estratégias que envolvem a ação do Estado (políticas públicas), da comunidade e de indivíduos (protagonismo e desenvolvimento de 
habilidades pessoais), do sistema de saúde (reorientação do sistema de saúde) e de parcerias interinstitucionais, trabalhando com a concepção de responsabilização múltipla, seja pelos problemas, seja pelas soluções propostas para os mesmos. ${ }^{4}$

Tendo a perspectiva da intersetorialidade como estratégia de atuação pensamos em desenvolver ações em saúde, educação, trabalho, lazer, cultura e mobilização social voltadas ao empoderamento de indivíduos de modo que possam vir a desenvolver práticas que resultem na promoção, proteção e defesa de suas condições de vida e saúde. Sendo assim, nosso principal objetivo é impulsionar mulheres em situação de aprisionamento e que encontram-se em sofrimento psíquico e em vulnerabilidade social, seja por condições socioculturais anteriores ao aprisionamento e/ou pelo próprio encarceramento e serem mais protagonistas de sua própria história. ${ }^{13} 200$

\section{RESPONSÁVEIS PELA EXECUÇÃO DA AÇÃO}

A Penitenciária Modulada de Montenegro possui uma equipe de saúde prisional e uma equipe psicossocial. A equipe responsável pelo projeto é a da saúde que é composta por 01 enfermeira, 01 psicóloga, 01 assistente social e 01 dentista que compõe a equipe na contrapartida da SUSEPE. A técnica de enfermagem e o médico da equipe de saúde são contrapartidas no município. A ideia é que todos os profissionais participem ativamente das ações e que os demais profissionais que atuam no presídio possam contribuir para o bom funcionamento das atividades.

\section{PERÍODO E LOCAL}

As atividades a serem desenvolvidas ocorreram de maio de 2013 a maio de 2014 e foram desenvolvidas no interior da penitenciária por se tratar de detentos de regime fechado.

\section{DEFINIÇÃO DOS OBJETIVOS DA AÇÃO}

Propor promoção de saúde através de ações que abordem diferentes aspectos da vida dos nossos usuários é ampliar as ações de saúde para algo mais atual e inovador, tendo como objetivo atividades que visem uma maior aproximação dos nossos usuários com o consequente protagonismo social de todos os envolvidos. Além disso, urge a necessidade de adequarmos metodologias de trabalho à uma prática mais atual e próxima dos profissionais em saúde do contexto sociocultural do público com que lidamos, assim como o empenho para maior ampliação do matriciamento das ações em saúde do SUS.

\section{AÇÕES DESENVOLVIDAS}

Segue abaixo as ações propriamente ditas do plano de ação: 
» Buscar e incentivar o matriciamento entra ações de saúde da penitenciária com ações de saúde desenvolvidas no município de Montenegro;

» Desenvolver ações de arte, dança e produção literária em parceria com a Universidade Estadual do Rio Grande do Sul;

» Fazer rede de contato com ONGs religiosas;

»Desenvolver palestras voltadas à saúde integral das mulheres através de parceria com profissionais da área da saúde;

» Propor ações através da ONG Embaixatrizes da Solidariedade;

» Incluir detentas nos cursos do programa Pronatec;

» Implantar biblioteca no anexo feminino.

As ações propostas ocorreram conforme o estabelecimento das parcerias de trabalho.

\section{RECURSOS ENVOLVIDOS}

As ações propostas em nosso plano não terão custos financeiros diretos, pois contam com o trabalho voluntário das instituições, assim como inclusão em ações da Atenção Básica do município de Montenegro. Para o desenvolvimento de algumas atividades iremos utilizar Aparelhos multimídia, computadores, aparelhos de som, materiais de escritório, palestrantes qualificados.

A penitenciária Estadual Modulada de Montenegro possui parceria com o Conselho da Comunidade do município onde através de projetos é possível obter insumos e dispositivos necessários para realização de ações inclisas em projetos. Também é possível angariar apoio com o ONG Embaixatrizes da solidariedade: grupo de senhoras que desenvolve ações assistencialistas.

\section{ANÁLISE DOS RESULTADOS}

As ações foram desenvolvidas a partir do mês de maio de 2013. Durante todo o ano de 2013 a equipe técnica iniciou o processo de articulação com a rede de serviços de saúde e com a rede de assistência social, pleiteando a participação em reuniões com a rede de saúde, assim como com o Conselho da Comunidade do município de Montenegro no intuito de partilharmos a realidade vivenciada na Penitenciária.

Ao iniciarmos este projeto procuramos avaliar os nós críticos das ações a serem desenvolvidas. É importante que se verifique tudo aquilo que não está acessível a equipe para que a mesma tenho um foco de trabalho. ${ }^{10}$ A Penitenciária Modulada de Montenegro possui muitos recursos críticos a começar pela sua localização - $37 \mathrm{~km}$ da capital Porto Alegre, $22 \mathrm{~km}$ do centro do município de Montenegro. Os funcionários que atuam nesta penitenciária enfrentam um difícil acesso ao local pela falta de 
locomoção pública, pela escassez de viaturas que possam deslocar os mesmos, assim como os apenados que precisam de atendimentos médicos ou remoção.

No ano de 2013 os servidores da SUSEPE, conquistaram uma nova forma de provento financeiro, o que implicou no aumento de salário dos mesmos. Entretanto, este aumento fez com que a pouca disponibilidade de funcionários em todo estado se mostrasse com maior visibilidade, pois o número de horas extras e diárias diminuíram, o que acarretou na diminuição do efetivo profissional na área da segurança do presídio. Em algumas quinzenas contamos com 02 agentes penitenciários fazendo a segurança de 230 apenados, por exemplo. Esta situação dificulta a realização dos atendimentos psicossociais, e até mesmo os de saúde, pela falta de efetivo segurança dos profissionais.

Outro aspecto importante é a dificuldade de vínculo com a Secretaria de Saúde do município de Montenegro. A Penitenciária está sem médico clínico geral desde março deste ano, o que implica na necessidade de locomoção dos apenados necessitados para hospital de alta complexidade e até mesmo para as referências da capital: Hospital Vila Nova, Hospital Conceição e Instituto Psiquiátrico Forense. Os psiquiatras do sistema se encontram lotados no Instituto Psiquiátrico forense e não se dispõe a deslocarem-se até Montenegro: realidade esta que retrata a precarização do atendimento em saúde.

\subsection{DISCUSSÃO DOS RESULTADOS}

Após articulação com a Universidade Estadual do Rio Grande do Sul foi possível iniciarmos nosso trabalho em sua primeira atividade com foco na cultura e Lazer.

\subsubsection{Apresentação de Teatro e Dança}

As primeiras atividades realizadas foram: a peça de teatro o Jardim das Cerejeiras e a apresentação e oficina de dança com o grupo: Mostra Transeutes do Projeto de Extensão da Universidade Estadual do Rio Grande do Sul.

Com o objetivo de elaborar as atividades oferecidas, o setor técnico da Penitenciária organizou uma roda de conversa ao final de cada atividade. Tanto o teatro como a dança trouxeram à tona muita reflexão e sentimentos os quais desencadearam o posicionamento crítico das mulheres. Para reiterar aquilo que debatemos solicitamos que as mulheres respondessem ao instrumento que continha a seguinte questão: relatem o que pensaram e sentiram ao assistirem as seguintes atividades: Peça de teatro "O jardim das Cerejeiras"; Apresentação de dança.

Com objetivo de melhor sistematizar o conteúdo das opiniões expostas optamos por dividir o material em categorias, conforme segue abaixo 


\subsubsection{Isolamento}

A privação da liberdade é algo avassalador para a grande maioria das pessoas. A segregação do indivíduo do seu grupo de iguais gera sofrimento e até mesmo adoecimento psicológico. A falta de contato com a sociedade e com os familiares potencializa sentimentos como a raiva, a culpa e a depressão.

A interação das apenadas com pessoas de fora do presídio trouxe à tona muitos sentimentos e opiniões. Foi uma ótima maneira de oportunizar à sociedade uma desmistificação acerca das pessoas que encontram-se presas.

"Foi interessante e uma bela distração para nós que estamos aqui e que não vemos o mundo lá fora";

“Gostamos muito da atividade e porque lembraram da gente. Muito bacana vocês lembrarem da gente, porque é poucas pessoas que tem visita"

“...muito interessante e importante saber que tem pessoas que se interessam em fazer essas apresentações pra gente, pois é muito ruim não ter contato com as pessoas. Muito obrigada por fazer a nossa vida um pouco mais feliz."

\subsubsection{Sentimento}

Ao falarmos e vivenciarmos qualquer expressão artística estaremos sempre falando daquilo que emociona o ser humano, daquilo que provoca sentimentos e emoções que podem promover a reflexão e a elaboração de ideias preconcebidas. Sentimentos como a depressão, a baixo autoestima, a intolerância, e a dificuldade em lidar com figuras de autoridade, são comuns no ambiente prisional. Ao assistirmos uma peça de teatro nos deparamos com a projeção de uma realidade com a qual podemos nos identificar. Discutir sobre a atividade ajuda a compreender melhor o que sentimos e verificar a opinião do mundo a respeito do que nos toca.

Esta forma de trabalhar saúde é muito importante para que os envolvidos possam compreender que seu sofrimento pode ser compartilhado com outra pessoa a qual também pode estar passando pela mesma situação. A partir disso, a equipe de saúde pode até mesmo pensar em uma Plano Singular Terapêutico coletivo.

"a dança nos trouxe alegria e diversão";

“...não é sempre que temos esta oportunidade aqui neste lugar. A gente se distrai e deixa um pouco a tristeza de lado"

"Muito obrigada por fazer a nossas vida um pouco mais feliz”

“...já estou há 4 anos aqui e fiquei muito feliz de poder assistir algo tão belo e emocionante” 
“...mais que um entretenimento, a visita deles foi um remédio para nossa alma e para o coração"

\subsubsection{Aprendizado}

Uma peça de teatro sempre fará alusão a uma experiência humana. Por isso, a tendência a estabelecermos analogias relacionadas ao nosso cotidiano é algo muito comum. Sendo assim, o teatro e a dança mobiliza reflexão e elaboração daquilo que foi experienciado por alguém. Se colocar no lugar do outro e poder pensar aquilo que queremos mudar para melhor é um movimento importantíssimos quando pensamos em saúde mental.

A prática da dança é uma forma de oportunizar uma atividade física e uma forma de trabalharmos a consciência corporal. Identificar nossas dores físicas e emocionais é primordial para pensarmos o que queremos de melhor em nossas vidas.

"O teatro nos mostra, nos ensina coisas que não dávamos atenção.

..."encontramos coisas valiosas, baseado em coisas de vida real”

“...essas atividades nos trazem uma mensagem positiva”

\subsubsection{Saúde e bem estar}

A saúde e o bem estar se relacionam com a promoção de saúde dos indivíduos. A prática de exercícios é algo pouco comum dentro dos estabelecimentos prisionais e que associados à má alimentação acabam acarretam problemas como a diabetes, a hipertensão, dentre outros.

Falar em bem estar dentro de casas prisionais parece algo um tanto antagônico já que as notícias sobre estas instituições nos mostram o exemplo da violação de direitos humanos. Entretanto, a realização de atividades lúdicas é possível e necessária dentro de ambientes como este.

“...naquela apresentação eu vi e senti que além de ser uma atividade física tira o stress, além de levantar a autoestima e o sedentarismo".

\subsubsection{Sentimento de pertença}

O encarceramento naturalmente segrega as pessoas, implicando diretamente na inserção desses sujeitos numa nova realidade: a do mundo do crime/ cárcere. Muitas mulheres insistem na questão de que não são bandidas e que não se identificam com este público. Por isso, nos cabe refletir sobre a importância do sentimento de pertencimento que essas pessoas devem ter em relação a sociedade a qual também compõe. Muito falamos em reinserção à sociedade para os que estão presos e este rótulo é carregado por muitas pessoas às quais passam a se questionar deste pertencimento ao virem presas. 
O preconceito gerado sob esta condição habita todos os indivíduos, os que estão presos e os em liberdade. Então, contarmos com a participam da sociedade em atividades dentro dos presídios é uma forma de compartilharmos a responsabilidade deste público para que possamos pensar de que maneira os sujeitos aprisionados podem retornar a sociedade, se inserir novamente e não regressar ao sistema prisional.

“...muito bom saber que há pessoas sem preconceito nessa sociedade doente, que acreditam que uma pessoa possa se arrepender do seu caminho."

“...não importa de onde eu vim, nem para onde eu estou, mas sim para onde podemos ir. Assim como eles nos trouxerem alegria a gente também pode levar alegria para as pessoas, assim podemos nos sentir menos excluídas do mundo"

\subsubsection{Formatura curso de Padeiro e Confeiteiro - Pronatec}

Essa atividade iniciou no ano de 2013 numa parceria entre governo do Estado, Senac/RS e SUSEPE. O Pronatec é um programa Nacional de ensino técnico que visa dar uma oportunidade às pessoas.

A implementação da atividade envolveu a equipe técnica da penitenciária, a equipe administrativa e o Departamento de Tratamento Penal da SUSEPE, os quais tiveram que unir esforços para colocar em prática o curso.

O aprendizado técnico retoma a questão do trabalho com finalidade educativa e produtiva e oportuniza às apenadas uma forma de romper com a ideia de que o trabalho prisional reproduz o mesmo cenário de profissões as quais muitas vezes são as que trazem a mulher ao cárcere.

Em que pese sabermos que padaria e confeitaria é uma profissão "dita feminina", o reconhecimento legal deste conhecimento técnico dá uma oportunidade legal de reingresso ao mercado de trabalho por parte dessas mulheres.

Durante o acompanhamento psicológico individual de 3 das mulheres que participaram deste curso é possível verificar um aumento da autoestima e uma reflexão maior sobre possibilidades de retorna à sociedade. As serem reconhecidas como aquelas pessoas que tem um conhecimento, sua autoestima se eleva e até mesmo as elaborações psicológicas a cerca de seu ingresso no cárcere começam a fazer mais sentido.

\subsubsection{Entrega de certificados - PAC Bombachas}

O Protocolo de ação conjunta com a empresa de confecção de bombachas Paisano já ocorre há muitos anos na Penitenciária, conforme reportagem em anexo. 
A ideia de fornecermos um certificado de aprendizagem de confecção de roupas gauchescas fortaleceu ainda mais a parceria e a vontade das apenadas em se inserir na atividade. Conforme fala de apenada: " ter um certificado na mão ajuda a gente a conseguir uma oportunidade de trabalho na rua. A gente aprende uma profissão e consegui se reerguer quando sair da prisão"

essa atividade ocorreu após tratativas entre empresa e direção e SETEC do estabelecimento num objetivo de efetivação e reconhecimento do trabalho desenvolvido pelas detentas com incremento da certificação como forma de promoção do conhecimento das mesma quanto ao ofício de corte e costura.

\subsubsection{Oficina de cabelereiro e apoio às familiares - ONG Embaixatrizes da Solidariedade}

Estas duas ações foram realizadas na parceria entre Setor Técnico da Penitenciária e a ONG Embaixatrizes da Solidariedade. A oficina de cabelereiro teve como objetivo ministrar conhecimentos sobre o ofício do corte de cabelo, associado a um espaço de autocuidado para as mulheres.

Algumas apenadas foram convidadas a cortar o cabelo e concomitantemente estimukadas a se olharem no espelho. Este foi um momento revelador: algumas apenadas choraram, outras se criticavam. De forma geral, o cuidado de sua própria imagem foi tema de conversa e de muita emoção durante a oficina.

A atividade de apoio aos familiares surgiu por parte da ONG que oportunizou à Penitenciária a inclusão de mulheres grávidas que visitam seus companheiros na lista de entrega de enxovais para bebês. A equipe técnica junto ao Setor de enfermagem organizou e entrega dos e ministrou uma fala sobre a importância do aleitamento materno e estímulo aos bons hábitos no puerpério, assim como o controle da natalidade através de práticas sexuais mais saudáveis e seguras.

\subsubsection{Parceria com banco de livros}

Através da parceria com o banco de livro e o Senai foi possível reorganizar a biblioteca existente no anexo feminino, além da humanização e reforma da sala de revista da Penitenciária. O local por onde os visitantes ingressam na Casa Prisional era um espaço muito desapropriado para a recepção de crianças e das pessoas de forma geral. Através desta parceria foi possível revitalizar o ambiente, compô-los com livros e revistas, além de brinquedos para que as crianças possam esperar o momento de ingressarem.

A organização da biblioteca do Anexo Feminino foi realizada em parceria com psicóloga e assistente social da equipe de saúde junto de uma apenada que catalogou todos os livros. Após esta organização começamos a distribuição dos mesmos. Durante os atendimentos individuais foi possível 
verificar a influência da leitura na vida de muitas mulheres. O hábito da leitura trouxe um aumento na autoestima e um sentimento de liberdade ao adentrarem nos universos retratados nos livros.

\subsubsection{Ações para o cuidado integral à saúde das mulheres}

Em junho de 2013 a equipe de saúde, representada pela psicóloga e enfermeira convidaram uma apenada a ser representante de saúde do grupo de mulheres presas. A ideia era poder colher informações a cerca de quais as principais necessidades em saúde e dúvidas do grupo.

A apenada escolhida para o trabalho trouxe para a equipe que as principais questões envolviam as DST's/HIV e questões nutricionais. A equipe fez contato com rede de saúde do município para convidar algum profissional para tratar dos assuntos pontuados pelo público, porém não tivemos êxito não somente pela falta de profissionais a palestrarem, como também pelo impedimento por parte de quem se prontificou a tal, pelo difícil acesso. Neste momento, o que conseguimos foi um material didático relativo as DST’s ofertado pela Saúde Prisional do Estado.

Em parceria com a Delegacia Penitenciária Feminina a equipe de saúde da penitenciária entregou a todas as mulheres presas o manual para liberdade. Este manual contém informações a cerca de direitos em saúde e assistência social. Todas as apenadas receberam o material o qual foi tema de atendimento psicológico individual.

Em parceria com a secretaria de saúde do estado, no núcleo de saúde da mulher procuramos a inclusão da penitenciária para o Mama Móvel: programa de saúde que realiza mamografia em todas as mulheres de uma região. A penitenciária foi incluída no cronograma da secretaria, mas não foi priorizada por se tratar de uma cadeia com 47 apenadas. Até a finalização deste trabalho de conclusão a penitenciaria ainda não foi comtemplada.

\subsubsection{Parceria com ONG religiosas}

Através da parceria com a Sociedade Bíblica do Brasil conseguimos a doação de muitas bíblias para a biblioteca do Anexo Feminino. Esta doação veio oficializada com um culto da Igreja evangélica a qual realiza trabalho voluntário todas as semanas através de encontros dentro das penitenciarias.

A Igreja Batista também frequenta a penitenciária todas as semanas e realiza um trabalho de evangelização das apenadas. Esses cultos religiosos são uma forma de catarse para as mulheres as quais, muitas vezes choram e se emocionam durante o culto. Durante o encontro o pessoal canta e conversa bastante sobre suas vidas, o que funciona como autoajuda, segundo fala das algumas detentas. 


\section{AVALIAÇÃO DO PROJETO}

Os indicadores para avaliação do projeto tiveram como referência a Pesquisa de perfil realizada na etapa de Análise Situacional da população carcerária, as pesquisas de opinião com as apenadas das ações desenvolvidas, e as opiniões dos atores envolvidos nas ações via reportagens publicadas em site oficial da instituição SUSEPE.

De forma geral, as ações as quais nos propusemos a realizar foram feitas e tivemos êxito no desenvolvimento. Sabemos que as ações intersetoriais envolvem a participação de muitos setores, o que implica na necessidade do monitoramento constante dos passos do projeto.

Penso que um dos pontos frágeis do projeto foram as ações de saúde propriamente dita. A articulação com a rede de assistência à saúde do município do Montenegro é frágil, inclusive porque o próprio município enfrenta dificuldades, como a escassez de profissionais. Outro fator importante no que concerne este assunto foi o meu afastamento da Penitenciária (licença maternidade), o que implicou na parada de estabelecimento de rede de apoio, assim como a continuidade dos acompanhamentos psicológicos individuais e planos singulares terapêuticos.

De forma geral, foi notório o melhor entrosamento entre as apenadas e a melhora no relacionamento entre apenadas e agentes penitenciários durante o curso das atividades proposta, o que nos aponta para um efeito psicológico quanto ao grupo como um todo.

\section{CONSIDERAÇÕES FINAIS}

A intersetorialidade é um recurso disponível da Atenção Primária à saúde, mecanismo esse que gera novas possibilidades de prestação de serviços de saúde e de assistência social. Esse mecanismo de trabalho é um desafio a ser buscado pela equipe de saúde, pois ainda trabalhamos de maneira segmentada. ${ }^{12}$

Atualmente é possível reconhecer a importância do estabelecimento de redes de parceria com outros setores, no sentido de refletirmos sobre os problemas que encontramos e que nem sempre advém da falta de assistência de qualquer área, mas sim pela falta de resolutividade de outras áreas.

A intersetorialidade é um dos eixos estruturantes das políticas públicas de saúde e se aproxima como parte integrante do que atualmente vem se discutindo sobre o conceito de cidade saudável:

\footnotetext{
“ A cidade saudável é aquela em que todos os atores sociais em situação - governo, organizações não governamentais, sociedade civil organizada, famílias e indivíduos fazem uma aliança para transformar a cidade em um espaço de produção social e da saúde, desenvolvendo os capitais humanos, social e produtivo, de forma sustentada, exercitando políticas públicas integradas e intersetoriais, incentivando a participação pública e reduzindo as iniquidades, de forma a melhorar a qualidade de vida dos cidadãos. (MENDES, 1996, p. 259)
} 
A partir dessa perspectiva pensamos que a parceria com outras esferas do poder público e privado estimula a participação ativa da sociedade no que concerne o cárcere. Penso que somos parte disso, e temos responsabilidade sobre isso. Sendo assim, acreditamos trazer profissionais e estudantes para a prisão é uma forma de unirmos a necessidade com a possibilidade, visando proporcionar e ampliar o campo de acesso aos direitos dos usuários, bem como potencializar os serviços que empoderarão os usuários.

Cabe reconhecermos que a intersetorialidade é uma prática que devemos buscar cotidianamente, pois a escolha por essa estratégia alude à ideia de que as políticas públicas não podem ocorrer de forma desarticulada, sobretudo, quando se trata de ações voltadas ao combate à pobreza e à exclusão social. ${ }^{5}$

As atividades que desenvolvemos durante o ano de 2013 e que se estendem em 2014 são fruto de muito investimento e energia para que pudessem realmente acontecer. $\mathrm{O}$ isolamento físico da penitenciária é fator significativo não somente para receber pessoas, como para os profissionais que nela atuam. Cabe ressaltar a importância do apoio e da boa relação existente entre a equipe de saúde e direção da penitenciária, pois sem essa interação e troca não seria possível a realização de todo este trabalho.

\section{AGRADECIMENTOS}

Não teria conseguido finalizar este pós-graduação se não fosse a ajuda dos meus pais que foram incansáveis na parceria do cuidado do meu filho, da minha casa e da minha vida.

Agradeço também ao meu amor, meu amigo, meu príncipe: o pai do meu filho, que também foi fundamental durante este tempo de estudo e dedicação. TE AMO MUITO 


\section{APÊNDICES}

\section{NOTÍCIAS EXTRAIIDAS DO SITE OFICIAL DA SUPERINTENDÊNCIAS DOS SERVIÇOS PENITENCIÁRIOS DO RIO GRANDE DO SUL}

http://www.susepe.rs.gov.br/conteudo.php?cod_conteudo=1406\&cod_menu=4

\section{PARCERIA LEVA PEÇA TEATRAL PARA APENADAS DE MONTENEGRO}

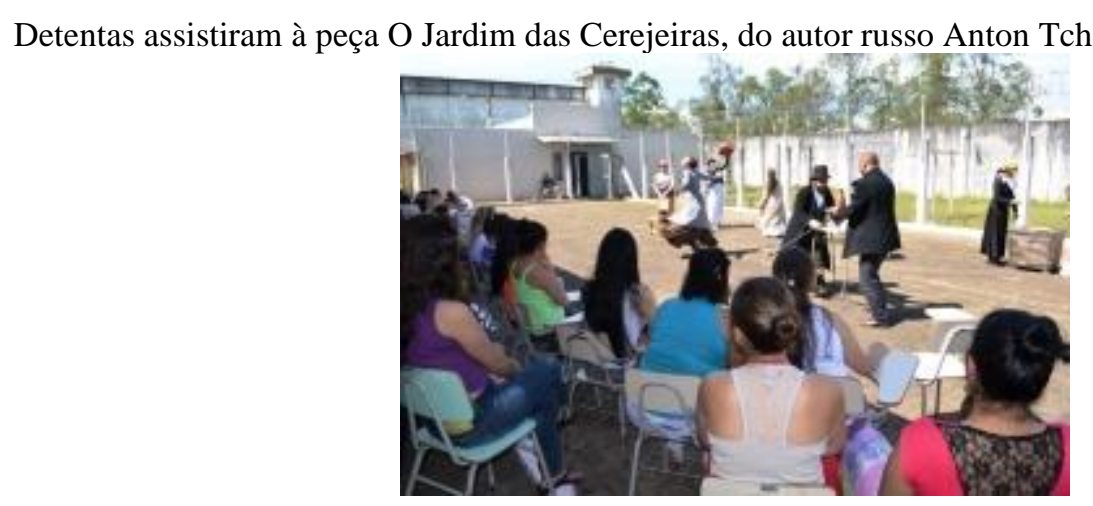

Cerca de 50 detentas da Penitenciária Modulada de Montenegro (PMM) assistiram na terçafeira (15), a peça "O Jardim das Cerejeiras", do autor Anton Tchekov (1860-1904). O ambiente do século passado de uma família aristocrática russa foi cenograficamente montado para apresentar o espetáculo, viabilizado pela parceria da Susepe, por meio da equipe técnica da PMM e UERGS.

Entre as ações de comédia e drama, as apenadas prestaram atenção, durante quase uma hora e meia de apresentação, com gargalhadas e olhares curiosos sobre os atores. De acordo com a equipe técnica, a ideia é promover diversas ações culturais em parceria com a universidade para o próximo ano.

A apenada, I.M., 28 anos, falou que estava com saudades de assistir a peças teatrais. "Na rua, eu sempre parava para ver, pois acho o teatro muito diferente das novelas", comparou.

A coordenadora da Assessoria dos Direitos Humanos da Susepe, Maria José Diniz, disse que "a iniciativa é importante, pois reestabelece a cidadania por meio da cultura, ocorrendo o empoderamento das mulheres na luta por busca de espaços e melhorias em todos os aspectos sociais". Sob a cordenação da diretora Tatiane Cardoso, onze atores participaram do espetáculo que foi apresentado no Anexo Feminino do estabelecimento prisional. 


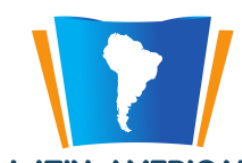

LATIN AMERICAN

Diretor da PMM, Rogério Ramos, disse que as ações culturais são importantes na inserção social das apenadas

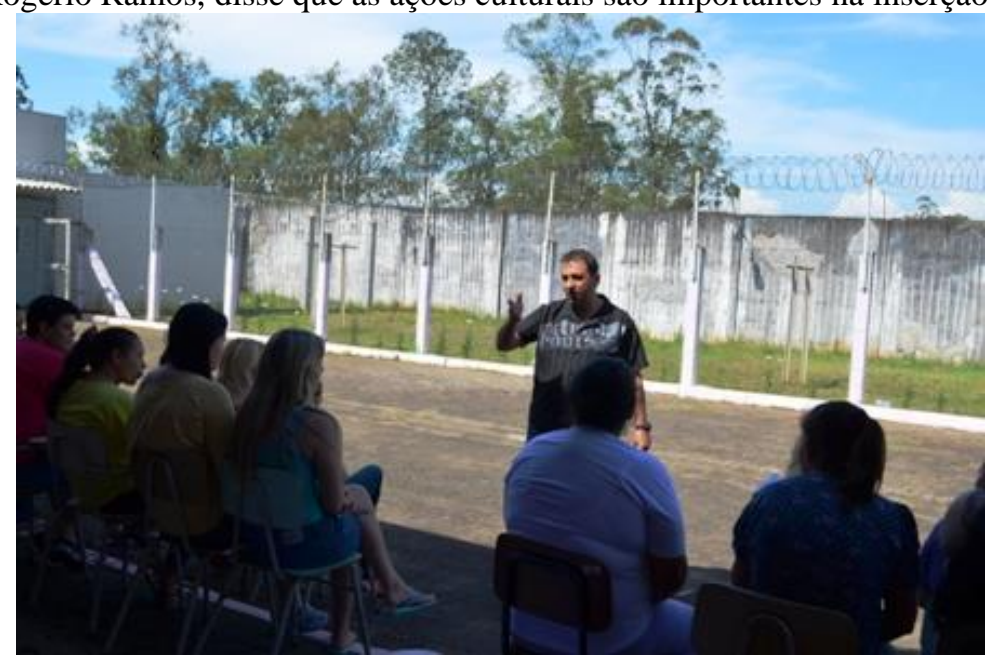

Entre gargalhadas e olhares curiosos, apenadas aplaudiram o espetáculo

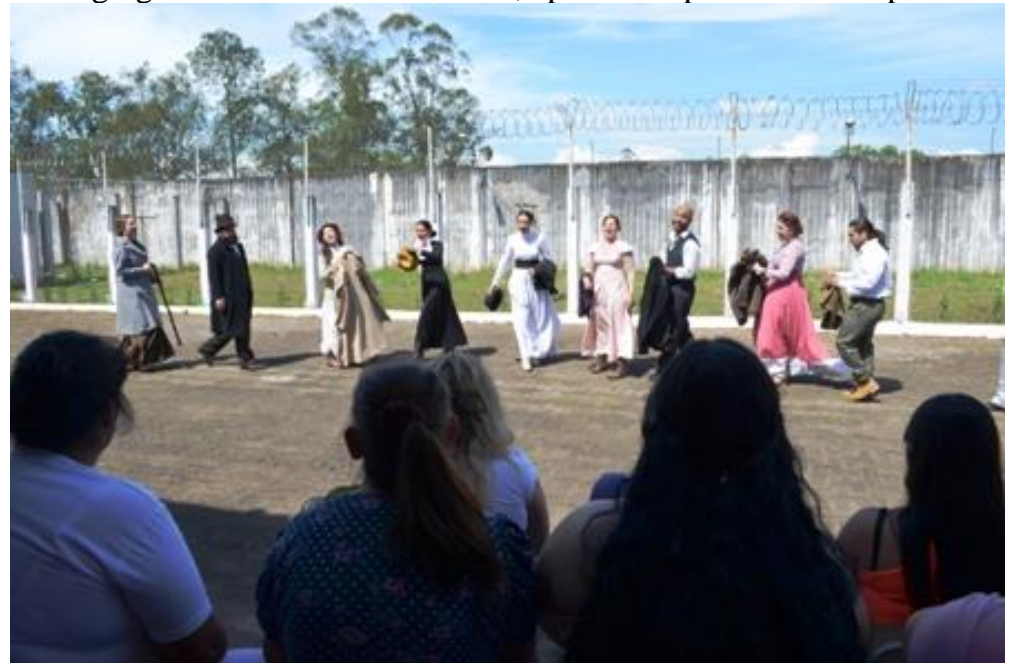

http://www.susepe.rs.gov.br/conteudo.php?cod_conteudo=1448\&cod_menu=4

TARDE DE DANÇA NA MODULADA DE MONTENEGRO - NOTÍCIA DO DIA 03.12.2013

Parceria da UERG e Susepe viabilizam ação artística nos presídios Foto de Divulgação PMEM

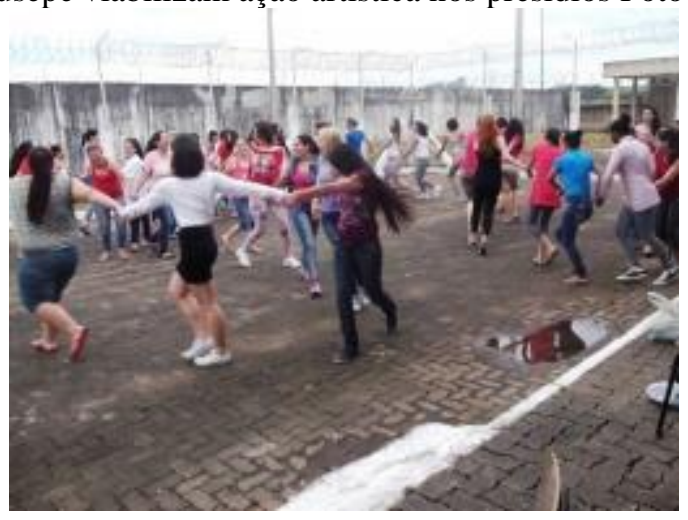


As apenadas da Penitenciária Modulada Estadual de Montenegro (PMEM), em parceria com a UERGS, apresentou, o espetáculo de dança, da Mostra Transeutes do Projeto de Extensão, no último dia 2, às 14 horas nas dependências da PMEM.

Sob coordenação da professora Sílvia da Silva Lopes, do curso de graduação em Dança, seis dançarinos participaram da mostra. Foram apresentadas quatro coreografias: Primavera Portenha (coreografia da companhia de dança Trupo Xipó Montenegro), Em-frente; Anoitecer e Yan Yang.

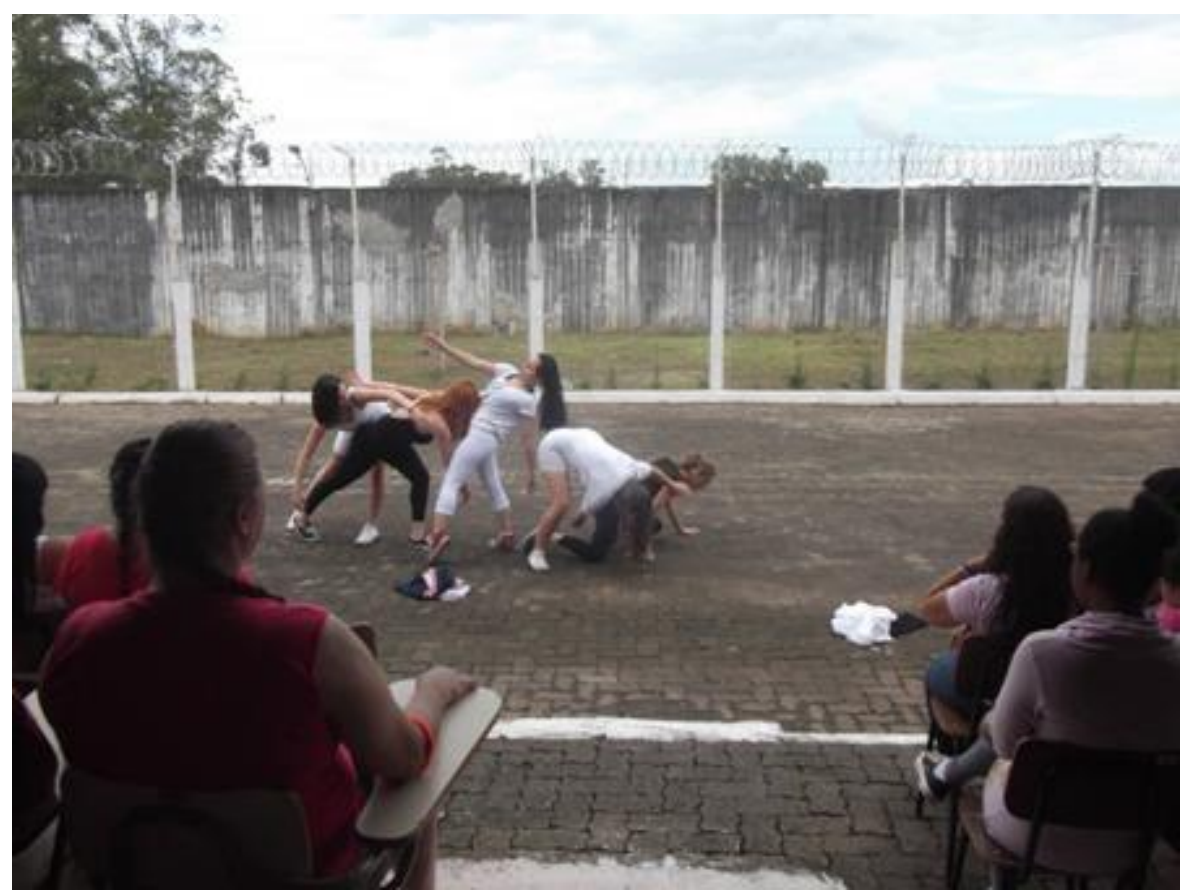

\section{INTEGRANTES DA MOSTRA DE DANÇA DURANTE APRESENTAÇÃO COMOVERAM APENADAS}

"Nesse sentido, a promoção destas apresentações contribuem para a expansão do olhar das apenadas frente às diferentes formas de cultura e expressão". A equipe da UERGS demonstrou interesse em implementar um projeto de criação de espaços culturais nos estabelecimentos prisionais, após ouvir relatos das apenadas que se interessaram em participar de ações artísticas, informou Luciana. De acordo com a apenada, indígena, C.F.. "No futuro gostaria de levar meus filhos para assistir espetáculos artísticos. A dança faz parte de sua cultura. "lá dançamos para cultuar a terra e a vida". 
http://www.susepe.rs.gov.br/conteudo.php?cod_conteudo=1416\&cod_menu=4

\section{PENITENCIÁRIA DE MONTENEGRO HUMANIZA ESPAÇO DE VISITAS - NOTÍCIA DO}

DIA 23.10.2013

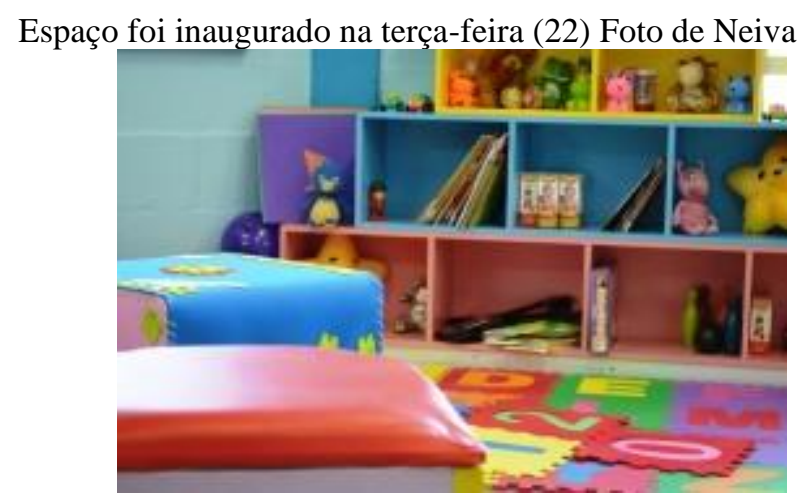

O hall de cerca de seis metros quadrados recebeu cores e decoração para acolher os visitantes dos apenados da Penitenciária Modulada de Montenegro (PMM). A ação foi uma iniciativa da Susepe, Banco de Livros e UniRitter, que desenvolveu o projeto por meio dos alunos do curso de Design. A mão de obra foi feita por três apenados, que pintaram, arrumaram a parte elétrica e fizeram a limpeza do espaço.

O diretor da PMM, Rogério Ramos, informou que a ação está embasada no artigo 23 da Lei das Execuções Penais (LEP), que trata da promoção no estabelecimento de espaços e amparos dos familiares. Organizada pelas assistentes sociais e psicólogas da PMM, a "iniciativa visa reduzir o impacto de sofrimento a quem entra nas prisões para visitar familiares apenados", concluiu o diretor.

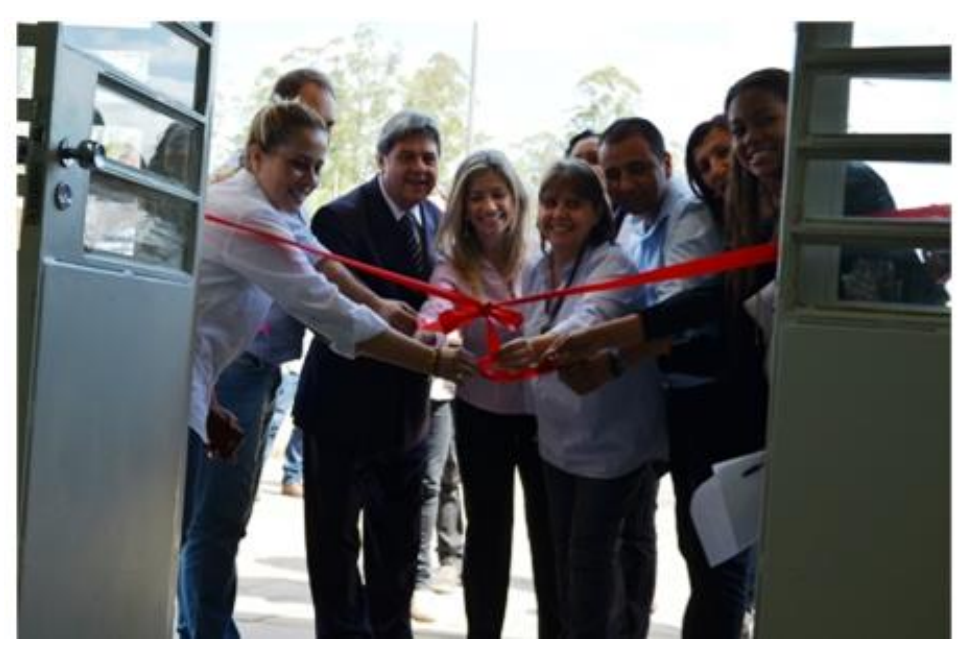


DIRETOR DA FUNDAÇÃO GAÚCHA DOS LIVROS,(TERNO) PAULO RENÊ, INAUGUROU O ESPAÇO DE ACOLHIMENTO MAIS HUMANIZADO VIABILIZADO PELA PARCERIA COM A SUSEPE E UNIRITTER.

Para a assistente social, umas das organizadoras da ação, Tamires Viegas, o ambiente ficará mais agradável também para os servidores penitenciários, que terão à disposição um local menos estressante para o trabalho. O apenado P.R, 36 anos, disse que foi uma oportunidade ímpar em contribuir com a nova arquitetura. "Em pensar que meus filhos poderão brincar aqui, me deixa menos ansioso, pois ficará mais confortável para a criançada", enfatiza.

\section{NOVO ESPAÇO}

De um lado da sala, foram postas seis cadeiras confortáveis para os adultos e, do outro, quadronegro, puffes, brinquedos pedagógicos mesinhas e cadeiras para entreter as crianças enquanto os pais aguardam a vez da revista. O coordenador do projeto de Design Social Aplicado/UniRitter, Cláudio Salvalaio, destacou o trabalho de seus doze alunos. "Eles buscaram levar mais alegria e cor ao espaço", disse o profissional, acrescentando que trata-se do primeiro trabalho de design desenvolvido pela equipe.

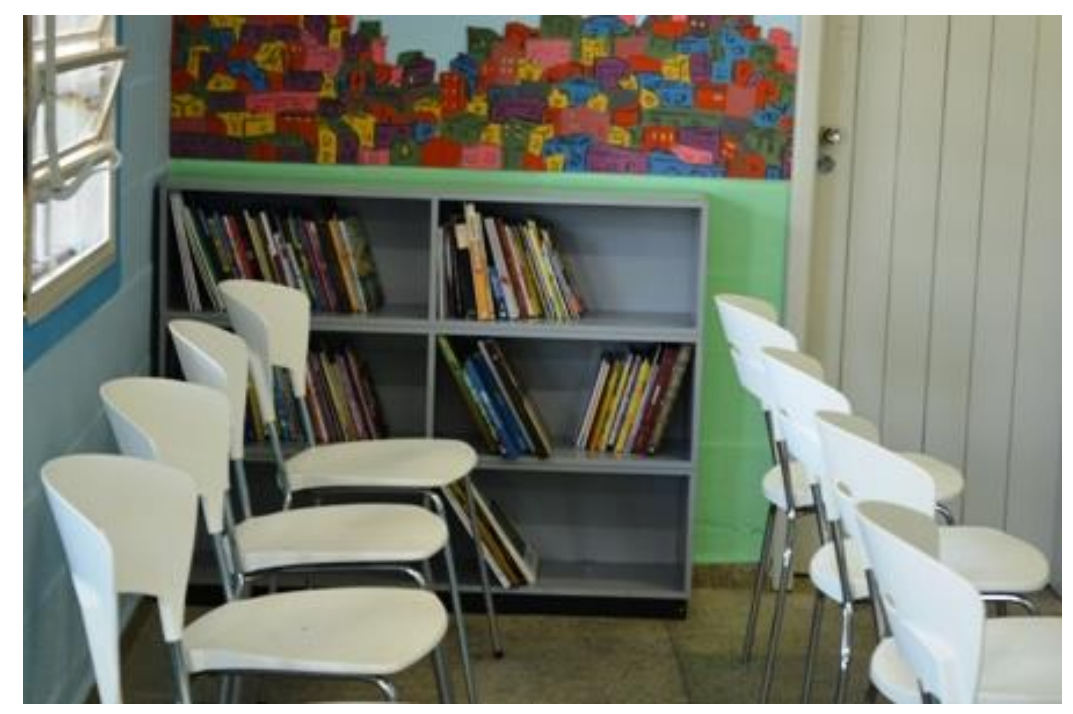

\section{ESPAÇO MAIS CONFORTÁVEL DESTINADO AOS ADULTOS VISITANTES COM ACESSO À LEITURAS BANCO DE LIVROS}

"Atingir a todas as casas prisionais no RS para fazer circular o conhecimento é a nossa meta", explicou a gestora do Banco dos Livros, Neli Miotto. Já são 84 estabelecimentos prisionais que tem espaço de leitura, com melhor acolhimento garantidos pela parceria com a Fundação Gaúcha dos Bancos Sociais. 
Um trabalho de recreação e atividades pedagógicas deverá ser desenvolvido por uma técnica de enfermagem para acolher melhor as crianças que visitam os pais na prisão. A ideia é inédita e deverá começar já na primeira quinzena de novembro.

http://www.susepe.rs.gov.br/conteudo.php?cod_conteudo=949\&cod_menu=4

\section{PRESAS RECEBEM DIPLOMA EM CURSO DE CONFECÇÃO DE BOMBACHAS EM MONTENEGRO}

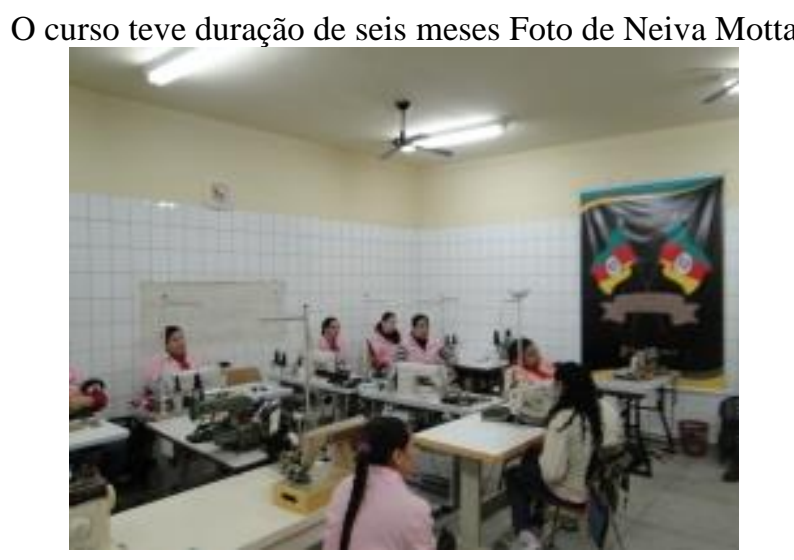

A Superintendência dos Serviços Penitenciários (Susepe) realizou nesta sexta-feira (27) a formatura de dez presas do curso de corte e costura de bombachas. As detentas produzem em média cerca de 30 unidades por dia. No atelier montado na Penitenciária Modulada Estadual de Montenegro (PMEM) cada uma tem a responsabilidade pela produção de uma parte da peça.

Para o diretor da casa, Paulo Fernando Soares Machado, a ressocialização, por meio do trabalho prisional e cursos profissionalizantes, está entre as prioridades da administração atual. De acordo com Loivo Lima Machado, do Setor de Valorização Humana da PMEM, a unidade de confecção das bombachas campeiras tem contribuído de forma efetiva para viabilizar possibilidades de trabalhos após cumprimento de pena. "O ambiente funciona de forma muito profissional e com metas", diz. O curso de corte, costura e modelagem teve duração de seis meses e foi ministrado pela dona Beatriz Moraes, sócia da confecção.

\section{EXPANSÃO E EMPREGO}

Para o empresário Tiago Moraes, dono da confecção,com sede em Novo Hamburgo, propiciar trabalho e renda às apenadas, além de contar com o trabalho delas, institui-se uma relação de muita confiança. Além disso, anunciou o empresário, todas as presas terão possibilidades de se empregar na 
sede da confecção após a condição de liberdade. "Elas terão a chance de recolocação imediata no mercado de trabalho, na área de costuras, basta manifestar interesse, disse.

Moraes disse que a empresa projetou a expansão no mercado para atender aos novos clientes, quando surgiu oportunidade de formar parceria com o trabalho prisional. "As presas têm superado as expectativas de estabelecidas por nós”, afirma.

http://www.susepe.rs.gov.br/conteudo.php?cod_conteudo=1543\&cod_menu=4

\section{MODULADA DE MONTENEGRO REALIZA FORMATURA DE APENADAS NO CURSO DE PADARIA E CONFEITARIA - NOTÍCIA DO DIA 07.05.2014}

Diversos cursos de qualificação são promovidos no sistema prisional Foto de Neiva Motta/Arquivo Susepe

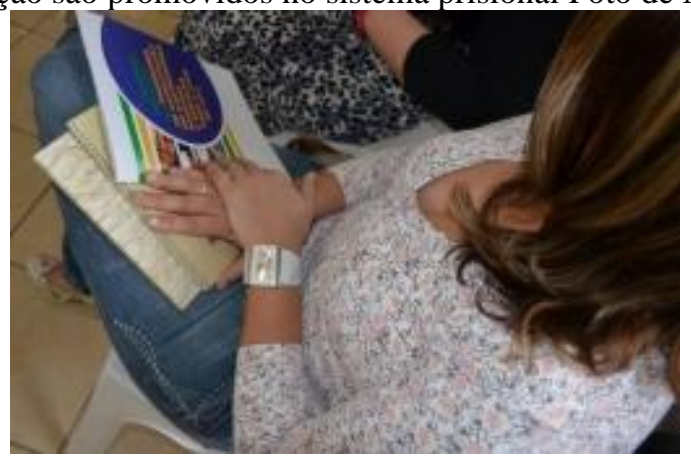

A Superintendência dos Serviços Penitenciários (Susepe) realizou, nesta terça-feira (6), a formatura de apenadas da Modulada de Montenegro no curso de Padaria e Confeitaria. O curso foi ministrado pelo Senac, por meio do Pronatec Prisional, e teve carga horária de 300 horas. Treze apenas concluíram o curso.

"Na ocasião, entregamos certificados somente a quatro formandas, em razão das demais estarem em liberdade ou terem sido transferidas para outros estabelecimentos prisionais", informou a assistente social da penitenciária, Tamires Viegas. O diretor do estabelecimento prisional, Rogério Ramos, garantiu que os certificados serão entregues após contato com familiares.

De acordo com a diretora do Senac, Sílvia Guterres, o programa propicia educação para todos os níveis, direcionando-as para o mercado de trabalho, "além de contribuir para o crescimento pessoal". "O curso serviu como uma ferramenta de minha inserção no mercado de trabalho. Depois deste curso, em liberdade, vou trabalhar na padaria recém adquirida pela família", disse a apenada C.T. 


\section{BIBLIOGRAFIA}

1. Barcinski, MA. Mulheres no tráfico de drogas: a criminalidade como estratégia de saída da invisibilidade social feminina. Rio de Janeiro: Contextos Clínicos; 2012 v. 5, p. 52-61

2. Brasil. Lei n. 7.210, de 11 de julho de 1984. Institui a Lei de Execução Penal. Brasília, DF. [Acesso em: 30 out. 2010]. Disponível em: http://www.planalto.gov.br/ccivil_03/Leis/L7210.htm.

3. Brasil. Ministério da Saúde. Portaria interministerial 1.777, de 05 março de 2003. Plano nacional de saúde no sistema prisional. Brasília; 2005.

4.Brasil. Ministério da Saúde. Acolhimento nas práticas de produção de saúde. $2^{\circ}$ ed. Brasília: Textos básicos de saúde; 2008. [Acesso em: 29 de maio de 2014] Disponível em: www.http/bvsms.saude.gov.br.bvs/publicações/acolhimento_praticas-produções_saude_2ed.pdf.

5. Bronzo C, Veiga L. Interdisciplinariedade e políticas de superação da pobreza. São Paulo: Serviço social \& sociedade - Cortez; n. 92, 2007

6. Buss PM. Uma introdução ao conceito de Promoção da Saúde. Rio de Janeiro: Editora Fiocruz; 2003.

7. Departamento Penitenciário Nacional. Sistema Integrado de Informações Penitenciárias INFOPEN.Brasil. [Acesso em: 11 de maio de 2013] Disponível em: http:www.portal.mj.gov.br/main.asp

8. Espinoza, O. A mulher encarcerada em face do poder punitivo. CIDADE: IBCcrim; 2004. Jul. p. 284-287.

9. Jardim, ACMG. Cartografias familiares no Presídio Regional de Pelotas. Pelotas. Monografia [Trabalho de conclusão do curso de Serviço Social] Universidade Católica de Pelotas; 2007.

10. Machado J de FFP. Gestão da atenção e saúde no sistema prisional: unidade IV: planejamento em saúde. Campo Grande: FIOCRUZ Pantanal; 2013.

11. Mendes EV. Atenção primária à saúde no SUS. Fortaleza: Escola de saúde pública do Ceará; 2002.

12. Paula K, Palha PF, PROTTI ST. Intersetorialidade: uma vivência prática ou um desafio a ser conquistado? CIDADE: Interface- comunicação, saúde, Educação; 2004. mar/ago; n.15 v: 8. p.331348.

13. Teixeira CF, Solla JP. Modelo de atenção à saúde: vigilância e saúde da família. Salvador: Editora EDUFBA; 2006. p. 237 [Acesso em: 30 de maio de 2014].Disponível em: http:www//books.scielo.org 